Proc. Indian Acad. Sci. (Chom. Sci.), Vol. 89, Number 2, April 1980, pp. 193-200. (C) Printed in India.

\title{
Molar volumes of ammonium chloride-ammonium salt solutions
}

\author{
R L BLOKHRA, S K AGARWAL and S S THAKUR \\ Chemistry Department, Himachal Pradesh University, Simla 171005 , India
}

MS received 15 May 1979 ; revised 25 October 1979

\begin{abstract}
The apparent molar volume of ammonium bromide and ammonium nitrate has been determined in various solutions of ammonium chloride at $30^{\circ} \mathrm{C}$ from density measurements using an hydrostatic balance. The molar volumes show a linear function of concentration. The values of $\mathrm{NH}_{4} \mathrm{Br}, \mathrm{NH}_{4} \mathrm{NO}_{3}$ are larger in $\mathrm{NH}_{4} \mathrm{Cl}$ solutions than in pure water and this has been attributed to the increase in the interactions of $\mathrm{NH}_{4} \mathrm{Br}$ and $\mathrm{NH}_{4} \mathrm{NO}_{3}$ with $\mathrm{NH}_{6} \mathrm{Cl}$. The mean apparent molar volume of $\mathrm{NH}_{6} \mathrm{Br}-\mathrm{NH}_{4} \mathrm{Cl}$ and $\mathrm{NH}_{4} \mathrm{NO}_{5}-\mathrm{NH}_{6} \mathrm{Cl}$ solutions have also been estimated directly from density measurements as well as from pure water data using Young's rule. The deviations are approximately studied as excess volume of mixing of $\mathrm{NH}_{4} \mathrm{Br}$ and $\mathrm{NH}_{4} \mathrm{NO}_{3}$ with $\mathrm{NH}_{4} \mathrm{Cl}$.
\end{abstract}

Keywords. Molar volumes; Young's rule ; solute-solvent interactions ; ammonium chloride; ammonium salt.

\section{Introduction}

During recent years, volume studies in mixed electrolyte solutions have been extensively studied to understand the interactions among electrolytes (Billi et al 1974; Blokhra et al 1977; Millero 1971; Ward and Millero 1974; Wells et al 1975). However, the behaviour of mixed electrolyte solutions has not bean studied in detail. The mean apparent molar volume $\phi_{0}$ of electrolyte-electrolyte solutions has been correctly estimated as a first approximation from molar volume data of these electrolytes in water using the additivity rule developed by Young (1951). Young's rule when applied to an electrolyte mixture is given by (Ward and Millero 1974)

$$
\phi_{v}=\sum_{i} y_{i} \varphi_{0}(i)
$$

$\varphi_{v}(i)$ is the apparent molar volume for electrolyte component $i$ in water at the same ionic strength as the totaf mixture and $y_{1}$ is the molar weighting factor $\left(y_{1}=\right.$ $m_{l} / m_{T}$ ) where $m_{i}$ is the molarity of the component $i$ and $m_{T}=\Sigma_{d} m_{1}$ is total molarity. This formula holds good for various multicomponent solutions. The present investigation attempts to verify Young's rule for mixtures of ammonjum salts and to study the deviations, if any, from Young's ruld interms of excess volume of mixing of two electrolyte solutions at constant ionic strength. 


\section{Experimental}

Ammonium chloride, ammonium bromide and ammonium nitrate of Analar grade were used without further purification. Water of specific conductance $10^{-6} \mathrm{ohm}^{-1} \mathrm{~cm}^{-1}$ was used for making different solutions. The density was measured with a hydrostatic balance (Blokhra and Agarwal 1979). A glass float $(116 \mathrm{~g})$ of volume $26 \cdot 17 \mathrm{ml}$ was used. The glass sample cell has a bakelite top with hole in the centre and is placed in a water bath which was further kept in an air thermostat controlled to better than $\pm 0.02^{\circ} \mathrm{C}$. The densities of the solutions were calculated from the equation

$$
d-d^{0}=\left(W^{0}-W_{l} / V\right)
$$

where $d$ and $d^{0}$ are the density of the sample and pure water respectively, $W$ and $W^{0}$ are the weights of float in the sample solution and pure water. $V$, is the volume of the float.

The ascuracy was checked by measuring the density of pure dioxane at $30^{\circ} \mathrm{C}$. The value of $d=1 \cdot 02230(4) \mathrm{g} \mathrm{cm}^{-3}$ obtained in the present work agrees with that of Timmermans (1950). The difference in weight of float in water and dioxane at $30^{\circ} \mathrm{C}$ was $\pm 3.0 \times 10^{-5} \mathrm{~g}$. All measurements in the present study were carried out at $30^{\circ} \mathrm{C}$.

\section{Results and discussion}

The densities have been measured for $\mathrm{H}_{2} \mathrm{O}-\mathrm{NH}_{4} \mathrm{Cl}, \mathrm{H}_{2} \mathrm{O}-\mathrm{NH}_{4} \mathrm{Br}, \mathrm{H}_{2} \mathrm{O}-\mathrm{NH}_{4} \mathrm{NO}_{3}$ and $\mathrm{NH}_{4} \mathrm{Cl}-\mathrm{NH}_{4} \mathrm{X}\left(\mathrm{X}=\mathrm{Br}^{-}, \mathrm{NO}_{3}^{-}\right)$solutions at $30^{\circ} \mathrm{C}$ at different concentrations. Tre apparent molar volume $\varphi_{0}$ of $\mathrm{NH}_{4} \mathrm{Br}, \mathrm{NH}_{4} \mathrm{NO}_{3}$ in $\mathrm{NH}_{4} \mathrm{Cl}$ solutions were calculated direstly from density data using the equation :

$$
\varphi_{0}=1000\left(d^{0}-d\right) /\left(m d d^{0}\right)+(M / d)
$$

where $m$ is the molarity of $\mathrm{NH}_{4} \mathrm{X}\left(\mathrm{X}=\mathrm{Br}^{-}, \mathrm{NO}_{3}{ }^{-}\right)$in $\mathrm{NH}_{4} \mathrm{Cl}$ solutions. $d$ is the density of the solution, $d^{0}$ is the density of the solvent $\left(\mathrm{NH}_{4} \mathrm{Cl}\right.$ solutions at $\left.m=0\right)$ and $M$ is the molecular weigit of $\mathrm{NH}_{4} \mathrm{X}$.

The apparent molar volumes of $\mathrm{NH}_{4} \mathrm{X}\left(\mathrm{X}=\mathrm{B} r, \mathrm{NO}_{3}{ }^{-}\right) \varphi_{0}$ thus calculated vary linearly with $m$ in different $\mathrm{NH}_{4} \mathrm{Cl}$ solutions at $30^{\circ} \mathrm{C}$. The $\varphi_{0}$ values calculated from (2) of $\mathrm{NH}_{4} \mathrm{Br}$ and $\mathrm{NH}_{4} \mathrm{NO}_{3}$ in $\mathrm{H}_{2} \mathrm{O}$ and in $\mathrm{NH}_{4} \mathrm{Cl}$ solutions at different concentrations are given in tables 1 to 3 .

The plots of $\varphi_{v}$ versus $\sqrt{ } m$ for $\mathrm{NH}_{4} \mathrm{Cl}-\mathrm{H}_{2} \mathrm{O}, \mathrm{NH}_{4} \mathrm{Br}-\mathrm{H}_{2} \mathrm{O}$, and $\mathrm{NH}_{4} \mathrm{NO}_{3}-\mathrm{H}_{2} \mathrm{O}$ are linear as shown in figure 1 . The apparent molar volume at infinite dilution has been calculated for different solutions by extrapolating the linear plots of $\varphi_{*}$ versus $m$. The limiting slope $S_{*}^{*}$ of these plots and $\varphi_{*}^{0}$ values have been recorded in table 4.

Since $S_{v}^{*}$ is the measure of ion-ion interactions (Horne 1972), higher values of $S_{v}^{*}$ suggest the formation of multi ions in the solutions at higher concentrations of ammonium chloride.

The volume properties of multicomponent solutions can also be conveniently treated (Ward and Millero 1974) by using the concept of mean apparent malal volume $\phi_{v}$. The mean apparent molar volume $\phi_{v}$ is given by

$$
\phi_{0}=1000\left(d^{0}-d\right) /\left(m_{T} d d^{0}\right)+\left(M_{T} / d\right) \text {, }
$$


Molar volumes of $\mathrm{NH}_{4} \mathrm{Cl}$-ammonium salt solutions

Table 1. The apparent molar volume $\varphi_{0}$ of $\mathrm{NH}_{4} \mathrm{X}$ in water at $30^{\circ} \mathrm{C}$.

\begin{tabular}{|c|c|c|}
\hline$m_{\mathrm{NR}, \mathrm{Cl}}$ & $-1000 \Delta d$ & $\varphi_{0}$ \\
\hline 0.05 & 0.67 & $36 \cdot 33$ \\
\hline $0 \cdot 10$ & $1 \cdot 68$ & $36 \cdot 88$ \\
\hline 0.15 & $2 \cdot 47$ & $37 \cdot 16$ \\
\hline $0 \cdot 20$ & $3 \cdot 10$ & $37 \cdot 55$ \\
\hline 0.25 & $4 \cdot 02$ & $38 \cdot 16$ \\
\hline $0 \cdot 30$ & $4 \cdot 38$ & $39 \cdot 00$ \\
\hline 0.35 & 5.09 & $39 \cdot 12$ \\
\hline 0.40 & $5 \cdot 55$ & 39.79 \\
\hline \multicolumn{3}{|l|}{$m_{\mathrm{NH}_{4} \text { nI }}$} \\
\hline 0.05 & $2 \cdot 62$ & $45 \cdot 70$ \\
\hline 0.10 & $5 \cdot 13$ & $46 \cdot 86$ \\
\hline 0.15 & $7 \cdot 44$ & $48 \cdot 64$ \\
\hline 0.20 & 9.89 & $48 \cdot 77$ \\
\hline $0 \cdot 25$ & $12 \cdot 25$ & $49 \cdot 23$ \\
\hline $0 \cdot 30$ & $14 \cdot 41$ & $50 \cdot 19$ \\
\hline $0 \cdot 35$ & $16 \cdot 28$ & $50 \cdot 71$ \\
\hline 0.40 & $17 \cdot 35$ & $51 \cdot 34$ \\
\hline \multicolumn{3}{|l|}{$m_{\mathrm{NI}_{6} \mathrm{NO}_{2}}$} \\
\hline 0.05 & $1 \cdot 55$ & $49 \cdot 21$ \\
\hline 0.10 & 3.08 & $49 \cdot 37$ \\
\hline 0.15 & $4 \cdot 52$ & $50.1 \%$ \\
\hline $0 \cdot 20$ & $5 \cdot 90$ & 50.73 \\
\hline 0.25 & $7 \cdot 16$ & $51 \cdot 28$ \\
\hline 0.30 & $8 \cdot 28$ & $52 \cdot 62$ \\
\hline 0.35 & 9.47 & $53 \cdot 19$ \\
\hline 0.40 & 10.65 & $53 \cdot 39$ \\
\hline
\end{tabular}

where $d^{0}$ is the density of pure water, $d$ is the density of solution, $m_{T}$ is the total molarity and $M_{T}$ is the mean molecular weight. $M_{T}$ of the solution is determined by equation (4)

$$
M_{T}=\sum_{1} y_{1} M_{4}
$$

where $M_{1}$ is the molecular weight of the component $i$ and $Y_{4}$ is the molar weighing factor. The mean apparent molar volumes of $\mathrm{NH}_{4} \mathrm{X}-\mathrm{NH}_{4} \mathrm{Cl}$ solutions were determined by using equation (3) and $\phi_{v}$ at $30^{\circ} \mathrm{C}$ are plotted against $\sqrt{ } m_{\tau}$ in figure 2.

The curves representing various concentration of $\mathrm{NH}_{4} \mathrm{X}$ solutions in $\mathrm{NH}_{4} \mathrm{Cl}$ solutions could not be extrapolated to a point corresponding to zero concentration of $\mathrm{NH}_{4} \mathrm{X}$ salts. This suggests solute-solute interactions in these multicomponent electrolyte solutions and $\phi_{r}^{0}$ cannot therefore be considered to be made up of two components. 
Tahle 2. The density and apparent molar volume $\varphi_{v}$ of $\mathrm{NH}_{4} \mathrm{Br}$ in $\mathrm{NH}_{4} \mathrm{Cl}$ solutions at $30^{\circ} \mathrm{C}$.

\begin{tabular}{|c|c|c|}
\hline$m_{\mathrm{NH}_{4} \mathrm{sr}}$ & $-1000 \Delta d$ & $\varphi_{v}$ \\
\hline \multicolumn{3}{|c|}{$m_{\mathrm{NH}_{4} \mathrm{Cl}}=0.01 ; d^{0}=0.99583(5)$} \\
\hline 0.05 & $2 \cdot 27$ & $52 \cdot 73$ \\
\hline $0 \cdot 10$ & $4 \cdot 73$ & $50 \cdot 87$ \\
\hline 0.15 & $7 \cdot 40$ & $48 \cdot 83$ \\
\hline $0 \cdot 20$ & 10.02 & $48 \cdot 11$ \\
\hline 0.25 & 12.90 & $46 \cdot 58$ \\
\hline 0.30 & 16.08 & $44 \cdot 58$ \\
\hline \multicolumn{3}{|c|}{$m_{\mathrm{MH}_{4} \mathrm{Cl}}=0.03 ; d^{0}=0.99613(6)$} \\
\hline 0.05 & $2 \cdot 50$ & $48 \cdot 13$ \\
\hline $0 \cdot 10$ & $5 \cdot 03$ & $47 \cdot 90$ \\
\hline 0.15 & $7 \cdot 53$ & 47.09 \\
\hline $0 \cdot 20$ & $10 \cdot 26$ & $46 \cdot 87$ \\
\hline 0.25 & $13 \cdot 32$ & $44 \cdot 90$ \\
\hline $0 \cdot 30$ & $17 \cdot 08$ & $42 \cdot 23$ \\
\hline \multicolumn{3}{|c|}{$m_{\mathrm{NH} 4 \mathrm{Cl}}=0.05 ; d^{0}=0.99633(6)$} \\
\hline $0 \cdot 10$ & $6 \cdot 48$ & $36 \cdot 24$ \\
\hline 0.15 & $8 \cdot 45$ & $41 \cdot 79$ \\
\hline 0.20 & $11 \cdot 24$ & $41 \cdot 94$ \\
\hline 0.25 & $13 \cdot 21$ & $45 \cdot 31$ \\
\hline $0 \cdot 30$ & $15 \cdot 78$ & $45 \cdot 54$ \\
\hline \multicolumn{3}{|c|}{$m_{\mathrm{NH}, \mathrm{Cl}}=0.070 ; d^{0}=0.99648(2)$} \\
\hline 0.10 & 5.95 & $38 \cdot 63$ \\
\hline 0.15 & $8 \cdot 28$ & $42 \cdot 92$ \\
\hline 0.20 & $10 \cdot 82$ & 44.04 \\
\hline 0.25 & 13.05 & $45 \cdot 95$ \\
\hline $0 \cdot 30$ & $15 \cdot 15$ & $47 \cdot 66$ \\
\hline \multicolumn{3}{|c|}{$m_{\mathrm{NH}_{4} \mathrm{Cl}}=0.09 ; d^{0}=0.99660^{\circ}(0)$} \\
\hline 0.05 & $2 \cdot 86$ & $40 \cdot 80$ \\
\hline $0 \cdot 10$ & $5 \cdot 26$ & $45 \cdot 54$ \\
\hline 0.15 & $7 \cdot 70$ & $46 \cdot 77$ \\
\hline 0.20 & $9 \cdot 90$ & $48 \cdot 66$ \\
\hline $0 \cdot 25$ & $12 \cdot 16$ & $49 \cdot 50$ \\
\hline 0.30 & $14 \cdot 38$ & $50 \cdot 21$ \\
\hline
\end{tabular}

Ward and Millero (1974) used Young's method of estimating mean apparent molar properties of mixed electrolyte solutions by considering the weighted additivity of the properties of electrolyte components in pure water to be equal to the properties of mixed electrolyte solutions. If we apply this to our system, the 
Table 3. Density and apparent molar volume of $\mathrm{NH}_{4} \mathrm{NO}_{3}$ in $\mathrm{NH}_{4} \mathrm{Cl}$ solutions at $30^{\circ} \mathrm{C}$.

\begin{tabular}{|c|c|c|}
\hline$m_{\mathrm{xaH}_{4} \mathrm{NO}_{3}}$ & $-1000 \Delta d$ & $\varphi_{v}$ \\
\hline \multicolumn{3}{|c|}{$m_{\mathrm{MH}_{4} \mathrm{Cl}}=0.01 ; d^{0}=0.99583(5)$} \\
\hline 0.05 & 0.22 & $75 \cdot 73$ \\
\hline 0.10 & $1 \cdot \overline{19}$ & $68 \cdot 37$ \\
\hline $0 \cdot 15$ & $2 \cdot 64$ & $62 \cdot 04$ \\
\hline 0.20 & $4 \cdot 83$ & 56.42 \\
\hline 0.25 & 6.95 & $52 \cdot 42$ \\
\hline $0 \cdot 30$ & $8 \cdot 66$ & $51 \cdot 32$ \\
\hline \multicolumn{3}{|c|}{$m_{\mathrm{NH}_{4} \mathrm{Cl}}=0.03 ; d^{0}=0.99613(6)$} \\
\hline 0.05 & 0.50 & $70 \cdot 27$ \\
\hline $0 \cdot 10$ & $1 \cdot 13$ & $67 \cdot 89$ \\
\hline 0.15 & $2 \cdot 80$ & $61 \cdot 52$ \\
\hline 0.20 & $4 \cdot 91$ & $55 \cdot 63$ \\
\hline 0.25 & $7 \cdot 14$ & $51 \cdot 63$ \\
\hline $0 \cdot 30$ & $9 \cdot 56$ & $48 \cdot 30$ \\
\hline \multicolumn{3}{|c|}{$m_{\mathrm{NH}_{\mathbf{c}} \mathrm{Cl}}=0.05 ; d^{0}=0.99636(3)$} \\
\hline 0.05 & $2 \cdot 30$ & $34 \cdot 02$ \\
\hline $0 \cdot 10$ & $4 \cdot 48$ & $35 \cdot 27$ \\
\hline 0.15 & $6 \cdot 14$ & $39 \cdot 16$ \\
\hline 0.20 & $7 \cdot 64$ & $41 \cdot 92$ \\
\hline 0.25 & $9 \cdot 29$ & 42.99 \\
\hline $0 \cdot 30$ & $9 \cdot 74$ & $45 \cdot 71$ \\
\hline \multicolumn{3}{|c|}{$m_{\mathrm{NH}_{4} \mathrm{Cl}}=0.07 ; d^{0}=0.99648(2)$} \\
\hline 0.05 & $2 \cdot 22$ & $35 \cdot 63$ \\
\hline $0 \cdot 10$ & $4 \cdot 38$ & $36 \cdot 25$ \\
\hline $0 \cdot 15$ & $6 \cdot 18$ & 39.91 \\
\hline 0.20 & $7 \cdot 69$ & 42.68 \\
\hline $0 \cdot 25$ & $9 \cdot 22$ & $43 \cdot 27$ \\
\hline $0 \cdot 30$ & $9 \cdot 72$ & $47 \cdot 76$ \\
\hline \multicolumn{3}{|c|}{$m_{\mathrm{NH}_{4} \mathrm{Cl}}=0.09 ; d^{0}=0.99660(0)$} \\
\hline 0.05 & $2 \cdot 02$ & $39 \cdot 65$ \\
\hline $0 \cdot 10$ & 3.75 & $42 \cdot 59$ \\
\hline 0.15 & 4.99 & $46 \cdot 96$ \\
\hline 0.20 & $6 \cdot 29$ & 48.69 \\
\hline 0.25 & $7 \cdot 67$ & $49 \cdot 46$ \\
\hline 0.30 & 8.91 & $50 \cdot 45$ \\
\hline
\end{tabular}




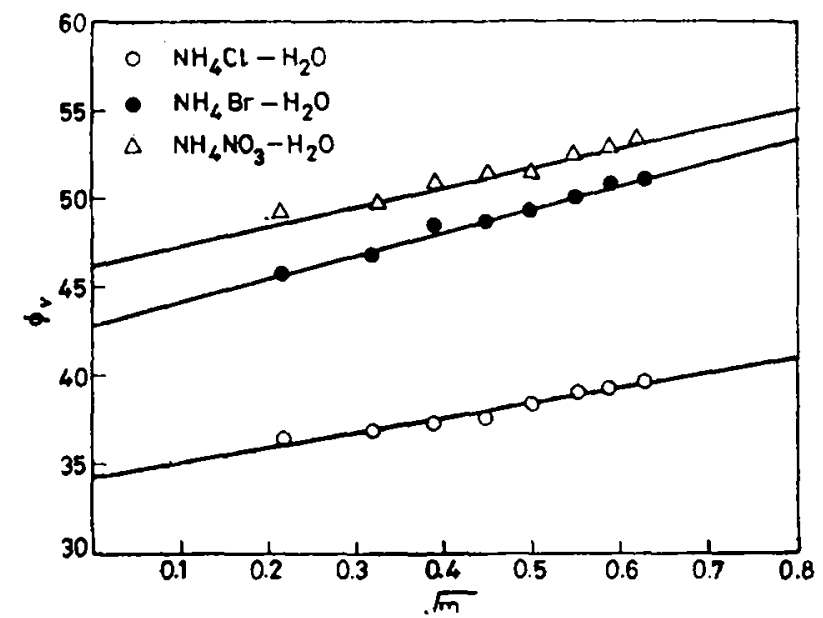

Pigure 1. Plot of $\varphi_{v}$ vs. $\sqrt{ } m$ for $\mathrm{NH}_{4} \mathrm{X}-\mathrm{H}_{8} \mathrm{O}$ at $30^{\circ} \mathrm{C}$.

Table 4. The partial molar volume at infinite dilution for $\mathrm{NH}_{4} \mathrm{Br}, \mathrm{NH}_{4} \mathrm{NO}_{3}$ i $\mathrm{NH}_{4} \mathrm{Cl}$ solutions at $30^{\circ} \mathrm{C}$.

\begin{tabular}{ccccc}
\hline$m_{\text {NH4 }}$ & $\varphi_{0}^{0}\left(\mathrm{NH}_{4} \mathrm{Br}\right)$ & $S_{*}^{*}\left(\mathrm{NH}_{4} \mathrm{Br}\right)$ & $\varphi_{0}^{0}\left(\mathrm{NH}_{4} \mathrm{NO}_{3}\right)$ & $S_{*}^{*}\left(\mathrm{NH}_{4} \mathrm{NO}_{3}\right)$ \\
\hline 0.01 & 53.00 & -31.43 & $81 \cdot 60$ & $-105 \cdot 50$ \\
0.03 & 50.00 & -24.00 & 79.40 & -88.80 \\
0.05 & 34.00 & 40.00 & $31 \cdot 60$ & 53.36 \\
0.07 & 37.00 & 42.80 & 33.40 & 76.40 \\
0.09 & 41.00 & 43.37 & 39.00 & 92.85 \\
\hline
\end{tabular}
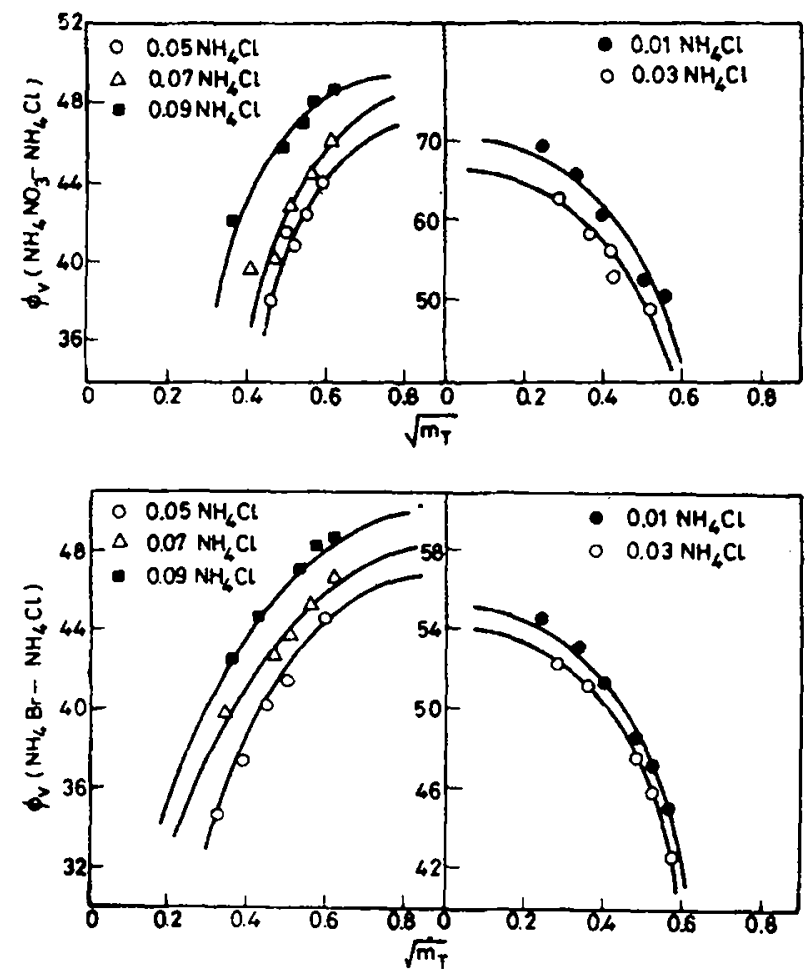

Froure 2. Plot of $\phi_{V}$ vs. $\sqrt{ } m_{T}$ for $\mathrm{NH}_{4} \mathrm{Br}-\mathrm{NH}_{4} \mathrm{Cl}$ solutions at $30^{\circ} \mathrm{C}$, 
mean apparent molar volume can be calculated from pure water molar volume data using equation (5) :

$$
\phi_{v}(\mathrm{cal} .)=y_{\mathrm{NH}, \mathrm{Cl}} \varphi_{0}\left(\mathrm{NH}_{4} \mathrm{Cl}\right)+y_{\mathrm{NH}_{0} \mathrm{x}} \varphi_{\bullet}\left(\mathrm{NH}_{4} x\right),
$$

wiere $\phi_{v}$ (cal) is the mean apparent molar volume calculated from pure water molar volume data

$$
y_{\mathrm{NH}_{6} \mathrm{X}}=\frac{m_{\mathrm{NH}_{6} \mathrm{X}}}{m_{T}}, \quad y_{\mathrm{NH}_{4} \mathrm{Cl}}=\frac{m_{\mathrm{NH}, \mathrm{Cl}}}{m_{T}}
$$

$\varphi_{v}\left(\mathrm{NH}_{4} \mathrm{X}\right)$ is the apparent molar volume of $\mathrm{NH}_{4} \mathrm{X}$ in water at $m_{T}$ and $\varphi_{6}\left(\mathrm{NH}_{4} \mathrm{Cl}\right)$ is the apparent molar volume of $\mathrm{NH}_{4} \mathrm{Cl}$ in pure water at $m_{\tau}$.

The difference in the observed $\phi_{v}$ values and values obtained from equation (5) is the excess molar volume for the mixing of two electrolytes and is given by equation (6):

$$
\phi_{v} \text { (obs.) }-\phi_{v}(\text { cal. })=\Delta \phi_{v} \text { (excess) } .
$$

The change in volume of mixing of the solutions of two electrolytes, $\Delta V_{m}$, calculated from equation (7) (Ward and Millero 1974)

$$
\Delta \phi_{v}(\text { excess })=\Delta V_{m} / m_{T},
$$

for $\mathrm{NH}_{4} \mathrm{X}-\mathrm{NH}_{4} \mathrm{Cl}$ solutions are plotted versus $Y_{B}\left(Y_{B}=m_{B} / m_{T}\right)$ in figure 3. This is of a large magnitude but parabolic curve with maxima around $Y_{B}=0.5$ for 0.01 , $0.03,0.05 \mathrm{~m} \mathrm{NH}_{4} \mathrm{Cl}$ solutions is similar to the curves for volume of mixing of other compounds. The large value of $\Delta V_{m}$ may be attributed to the non-validity of equation (5). However in case of 0.07 and $0.09 \mathrm{~m} \mathrm{NH} \mathrm{N}_{4} \mathrm{Cl}$ solutions, $\Delta V_{m}$ has been found to be more or less constant with $Y_{B}$ in the concentration range reported in the present investigation.

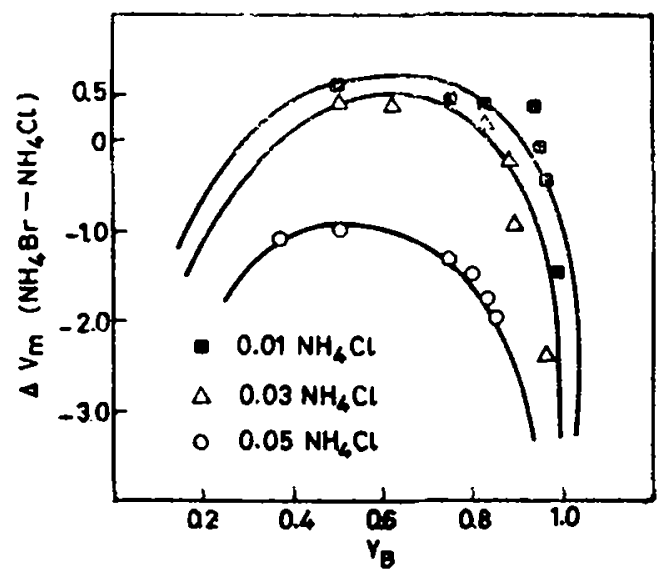

Figure 3. Plot of $\Delta V_{m}$ vs. $Y_{B}$ for $\mathrm{NH}_{4} \mathrm{Br}-\mathrm{NH}_{4} \mathrm{Cl}$ solutions at $30^{\circ} \mathrm{C}$. 


\section{Acknowledgements}

Two of the authors (SKA and SST) thanks the Council of Scientific and Industrial Research, New Delhi for the award of fellowships.

\section{References}

Billi A, Indelli A, Malatesta F and Zambomi R 1974 J. Chem. Phys. 614877 Blokhra R L, Agarwal S K and Sakhuja Neerja 1977 Electrochim. Acta 221083

Blokhra R L and Agarwal S K 1979 J. Chem. Thermodyn. 11229

Horne R A 1972 Water and aqueous solutions (New York : John Wiley) p. 522

Millero F J 1971 Chem. Rev. 71147

Timmermans J 1950 Physicochemical constants of pure organic compounds (Amsterdam : Elsevier) p. 502

Ward G K and Millero F J 1974 J. Solution Chem. 3431

Wells H L, Kustek M J and Lindstorm R E 1975 J. Solution Chem. 4391

Young T F 1951 Rec. Chem. Progr. 1281 